See discussions, stats, and author profiles for this publication at: https://www.researchgate.net/publication/326019627

\title{
Education as the Culture Process
}

Article in International Journal of Urban and Regional Research · June 2018

CITATIONS

2 authors, including:

Reza Rachmadtullah

2. PGRI University of Adi Buana

PGRI University of Adi Buana
26 PUBLICATIONS 29 CITATIONS

SEE PROFILE
READS

9 


\title{
Education as the Culture Process
}

\author{
Reza Rachmadtullah*, Dian Kusmaharti** \\ ${ }^{*{ }^{* * *}}$ PGRI Adi Buana University. Surabaya. Indonesia
}

\begin{abstract}
Education is practically inseparable from cultural values. in preserving and preserving its own culture, in its most effective transferring process by way of education. Both are very closely related to complement each other and support each other. The goal of education is to preserve and always improve the culture itself, with education we can transfer the culture itself from generation to generation. And also we as a society aspire to the realization of society and a better culture in the future, then it is by itself our education should be better again.
\end{abstract}

KEYWORDS : Education, culture

\section{INTRODUCTION}

Education and culture is the relationship of mutual influence, where education is the element that brings about a change of culture in the governance asymmetric relationship in which an element necessarily affect other elements. Education is also always changing according to the development of culture because education is a means of the cultural transfer process and mirror cultural values.

Education is a conscious and deliberate effort to create an atmosphere of learning and the learning process so that learners are actively developing the potential for him to have the spiritual power of religion, self-control, personality, intelligence, noble character, and skills needed him, society, nation, and state. (Article 1 ayat1 National Education System Law, 2007).

The interpretation of the above could mean that education is able to support the future development is education that can develop the potential of students, such that he would be able to have and solve the problems of education in the face it. Education must touch the inner potential and the potential competence of learners. The educational concept was even more important when a person has to enter the life in society and the world of work because he should be able to apply what is learned in school to deal with problems encountered in daily life today and tomorrow.

Mudyahardjo (2001) education is all life situations that affect the growth of the individual. Education within the narrow definition is the school. Education is held in school teaching as a formal institution. While education in alternative definition is a conscious effort made by the family, society and the government, through the guidance, teaching, and training, which takes place in school and out of school throughout life, to prepare students to be able to play a role in a variety of environmental right in the future. Education is a universal activity in human 


\section{International Journal of Multidisciplinary Approach}

ISSN NO:: $2348-537 X$

life. Education has existed throughout human civilization. Education is essentially a human effort to preserve his life. There is no life without their community education activities.

According to Daud Joesoef in Gunawan (2000: 30-11) Education is defined as a learning process that familiarize the citizens as early as possible to explore, understand, realize, control, appreciate, and practice all the agreed rate as laudable and desirable values, as well as handy for the life and development of the self, society, nation, and state. The values that are agreed to be developed through education rooted in (1) mind (logic), that is all true scientific fact recognized by the scientific world. (2) Feeling (aesthetics), are all works of art understood and implemented in daily life by the people regardless of the terms of their quality. (3) The will (ethics), the corresponding guidelines, such as character, personality, and religious sense.

The view of Ki Hajar Dewantara as the father of development education in the country of Indonesia. On the concept of the national culture known as the theory of Trikon. According to Ki Hajar Dewantara culture means the fruit of the human mind which is the result of the human struggle against two strong influence that is nature and the times (nature and society) (Tilaar, 2002: 43). (4) From the formula contains several things: (1) Culture is always nationality (national) and realize the nature or character of the national identity. (2) Every culture shows the beauty and humanity of indigenous high on a life of each nation who have it. (3) Each culture as a fruit of the victory of man against the power of nature and the times always facilitate and expedite his life and give new tools for the betterment of life and facilitate and drive the level and enhance their lives.

\section{THE ROLE OF FORMAL EDUCATION}

Education can be formed so that people can show their behavior as cultured beings who are able to socialize in their society and adapt to their environment in order to maintain the survival, personal, group, and society as a whole. School or formal education is one means or media from other media culture process (family and other institutions that exist in society).

It is in this context that education is called the process of manipulation (Dick Hartoko). In line with that, the anthropologists and other social scientists see education is an effort to civilize and socialize people we know with the enculturation, culture and socialization, the process of forming the personality and behavior of a child become a member of society so that children are tripped by people who do not. Culture fits with the ethnic group members we have. We used to call cultural identity (Perez.2004: 4).

Efforts to create attitudes and skills in community members so that they will be able to play roles in accordance with their respective positions and social roles in society. Indirectly this pattern becomes the process of preserving a culture. In line with this Bertran Russel said education as a social order of civilized life of society. Through education, we can form an advanced, modern, peaceful, peaceful and socially sustainable society based on cultural values and norms.

Graduates of educated people are expected to have positive attitudes embodied in the form of religious behavior, nimble, important, where each other where and what is bad, what is wrong and what is right, appreciate all the things that become part of life in this nature the form of a difference between fellow human beings. Have the ability to make the right decisions at a fast 


\section{International Journal of Multidisciplinary Approach}

pace and be able to develop self-potential in the effort to improve the quality of personal, family, group, religion, nation, and country. All these are essential elements in the process of building a prosperous, safe, just, prosperous and peaceful society.

In making this happen the education providers must be sure that the program and the learning process can lead students to be able to use all the things they have or who are experiencing the learning process. This can be useful in the next life both academic and everyday life.

\section{SCHOOL UNIT OR FORMAL EDUCATION AS THE CENTER FOR CULTURAL IMPLEMENTATION}

School as a formal education unit that prepares the young generation to face the modern generation, the school can educate the students by instilling the values of the nation's cultural character and school is expected to be a place of educational learning that is fun. The school in question is a school that is professed by Yehudi A. Cohen in Soedijarto (2015) quoted by: By a School I mean institution devoted to instruction, with specific personnel, permanent physical structure, special apparatus (of which text are important part), formal and stereotyped means of instruction, a curriculum, and rationally defined manifest objectives.

The results of education in schools are not entirely connected with the depravity of the community. Similarly, the various social, political, economic, and legal situations in society that exist in 'crisis' positions do not necessarily relate to educational outcomes in schools. However, there are certain aspects in the system of education in schools that still need to be observed, such as lack of attention to the function of schools as a cultural agent. This situation can be linked to policies at the macro level, in addition to the practice of organizing micro-education in schools.

The learning process or teaching and learning process as it is now does not automatically constitute the cultural process of the subjects being learned or taught. Subjects taught with emphasis on aspects of cognitive experience alone are not necessarily 'cultured' adequately in learners. That is, students may internalize the ability comprehension until the ability of synthesis in the relevant subjects, but not to touch the affective side, so there is no appreciation of the subjects. In other words, the learning process that occurs not to cause a sense of pleasure or love of what is learned.

Culture will occur if the learning process, in addition to stimulate and train the cognitive reasoning of learners, also evocative adequately affective reason. In a micro, the didactic methodology of the teacher with all the tips he uses will be enough to determine how far the students' affective side of a subject can be activated in the learning process so as to inspire and express his appreciation of what he or she learns. From another point of view, it is demanded that teachers not only emphasize instructional effects of the subjects they teach but also give sufficient attention to the nurturant effects that accompany the teaching and learning process.

Through the process of teaching and learning, teachers can also cultivate science and technology, which is a ery important role in the welfare of mankind. School is also an agent of cultural values of nationality and culture of the nation. As has been pointed out in the front of this paper, national education is a vehicle for the cultivation and development of the nation's culture. In the broadest sense, every part of the educational endeavor must not only 
refer to the cultural values of the nation but also be able to instill these values to the learners. Through national education efforts to promote national culture, which must be interpreted as an effort to educate the life of the nation and enhance the intellectual and professional abilities, attitudes, character and personality of a democratic and cultured Indonesian man (Soedijarto 1999).

Based on the above opinion the authors argue that the school as a cultural agent or school as agents of culture is required to be able to organize education that inculcates the nation's cultural values in order to strengthen the integrity and personality of the nation.

\section{CULTURAL PROCESS THROUGH FOUR PILLARS OF EDUCATION}

The process of culture (enculturation) through the four pillars of education is an effort to shape the behavior and attitude of someone who is based on knowledge, skills so that each individual can play their respective roles. Thus, the measure of the success of learning in the concept of enculturation is a change in student behavior. The 4 (four) pillars of education in the process of culture are:

\section{a) Learning to know}

According to Soedijarto in his paper Learning to Know is a process of learning that allows learners to master the techniques of acquiring knowledge and not merely acquiring knowledge. The author means that Learning to know is an effort to understand knowledge both as a tool and as a goal. As a tool of knowledge is expected to be useful in order to increase understanding, knowledge, and discovery in life (Aunurrahman, 2011).

\section{b) Learning to do}

According to Soedijarto in his paper, Learning to do contains meaning or implication about the necessity of professional education in a consequential way, which leads to a problemsolving paradigm that enables learners to integrate conceptual refinement, mastery of technical and intellectual skills, to solve problems and be able to continue innovation and improvisation. Based on the above description the author suggests that Learning to do more emphasis on how to teach children to practice everything that has been studied and can adapt the knowledge that has been obtained with the jobs in the future (Aunurrahman, 2011).

\section{c) Learning to live together}

Learning to live together is basically teaching, training and guiding learners so that they can create relationships through good communication, away from other people's bad prejudices and avoid and avoid conflict and conflict (Aunurrahman, 2011).

\section{d) Learning to be}

As expressly stated by the education commission, the fundamental principle of education should be able to contribute to the full development of every person, soul and body, intelligence, sensitivity, ethics, personal responsibility and spiritual values (Aunurrahman, 2011). 


\section{CONCLUSION}

Education is a cultural process to make human beings better and meaningful, while human beings will produce good culture if supported by broad education. In this context, education can not be separated from culture and culture can not be separated from education. Education is defined as a teaching-learning process that familiarizes the citizens as early as possible to explore, to understand, to realize, to master, to live, and to practice all agreed values as a worthy and desirable value, and useful for the life and development of the individual, and country. Through education and culture should the dreams and ideals of the nation can be realized that is the intellectual life of the nation

\section{REFERENCES}

i. Aunurrahman.(2011) "Belajar Dan Pembelajaran”.Bandung : Alfabeta.

ii. Bertha Perez, ed.,(2004) Sociocultural Contexts of Language and Literacy, London: Lawrence Erlbaum Associates

iii. H.A.R. Tilaar. (2002). Pendidikan Kebudayaan dan Masyarakat Madani Indonesia; strategi Reformasi Pendidikan Nasional. (Bandung: PT Remaja Rosdakarya). Hal. 43.

iv. Mudyahardjo,Redja. (2001). Pengantar Pendidikan Sebuah Studi Awal tentang DasarDasar Pendidikan pada Umumnya dan Pendidikan di Indonesia. Jakarta: PT Rajagrafindo Persada. 2001.

v. Pasal 1 ayat1 Undang-undang Sistem Pendidikan Nasional tahun 2007

vi. Soedijarto, (1999) "Otonomi Daerah dan Amanat UUD 1945 tentang Pendidikan Nasional dan Upaya Memajukan Kebudayaan Nasional”. Kongres Ilmu Pengetahuan Nasional VII. PUSPIPTEK Serpong, Tangerang. 1999.

vii. Soedijarto, (2015) "Curriculum System (Objectives, Learning Materials, Learning Models and Evaluation System) As Strategic Elements In The Implementation Of The National Education System And The Teacher's Stategic Role In Achieving The Implementation Of The Curriculum ". Presented in a National Seminar on the Role of Curriculum in Determining the Direction of Education Achievement of Indonesia by STKIP Kusuma Negara, October 22, 2015 as part of this paper has been presented also in the "National Education Convention" held by PB PGRI at Bentara Budaya Building on 19 February 2014.

viii. Soedijarto.(2015) "The intellectual life of the nation and the advancement of national culture is a mission which must be carried out through the holding of a national educational system". Paper presented in a discussion on Multicultural organized by presidential deliberation (WANTIMPRES) 26 November 2015.

ix. Zulfikri Anas, Pendidikan dalam Budaya, http://fikrieanas.wordpress.com, diakses 23 Februari 2016. 